\title{
Layered Language in Ayi Kwei Armah's the Beautiful Ones Are Not Yet Born
}

\author{
V Shantha*
}

\begin{abstract}
Language is used by writers in multiple ways to effectively convey the writer's vision. This paper explores the Ghanian novelist Ayi Kwei Armah's novel The Beautiful Ones Are Not Yet Bornand its layered use of language. How effectively can the realist mode portray a sense of deep despair? What are the layered levels at which language and narration must function to achieve the wrenching impact the author seeks to impart? What visual imagery or symbolic language can a writer use to convey the unconveyable? How can such elements be woven seamlessly into a realistic narrative? This paper examines some of these questions, and attempts to unravel the multiple ways in which descriptive language, revolting metaphors and nauseating scatological imagery are employed in the text.
\end{abstract}

Ghana or the Gold coast, as it was called during the British rule, was the first African nation to become a sovereign republic. In 1957, under the leadership of a popular figure-Kwame NkrumahGhana became independent. The country did not have any serious ethnic problems, the economy was stable, the administrative infrastructure was well organised and it had a dedicated and

* Department of English, Jyoti Nivas College, Bengaluru, India; drvshantha@yahoo.com 
educated ruler. Thus, Ghana at the time of independence seemed to be in a better position than other African countries. This illusion of stability was shattered in 1966 when Kwame Nkrumah was removed from power in an almost bloodless coup. While Nkrumah's deposition came as a surprise and a shock to most people outside the country, the people of Ghana had anticipated the coup and welcomed it when it took place.

The causes behind Nkrumah's fall were complex. Some Ghanians regarded their current form of government as an alien, unacceptable one. C.L.R James writes: "Nkrumah, like all African leaders and Asian leaders too has been fooling himself and a lot of other people with a dangerous fiction: its name is democratic socialism" (1977). The very foundation upon which the country's politics and future were based seems to have lacked popular support.

After Nkrumah's deposition, a radio announcement was made by the new military ruler who proclaimed to the country that, "After Ghana's accession to independence, a new class was formed whose principal occupation consisted of emptying the treasury and perpetrating crimes of all kinds under the pretext of creating a socialist state. Today Kwame Nkrumah and this new class have ceased to exist." (Fitch and Oppenheimer,1966) Thus corruption and embezzlement were also the alleged causes which precipitated the coup of 1966. In Ghana corruption has become the accepted national game extending from the clerical to the ministerial level.

In his enthusiasm to effect 'progress' and usher in 'civilization' in Ghana. Nkrumah had introduced various measures which resulted in an unnatural and rapid westernisation. Ghana after independence was no doubt ruled "by Africans, but Africans dominated by western ways of life and western ways of thoughts." A certain amount of discontent was therefore inevitable, and this came to a head finally in 1966. But even the coup has not really changed the situation in Ghana. V.S Naipul in his latest book Finding the Centre says: "Ghana, at the time of its independence in 1957 far richer and better educated ... was now after repeated coups in a state of anarchy, a source of migrant labour."(1984) 
While historians and political scientists analyse the situation by studying the factors that led to the corruption and the coup, its trajectory and aftermath in a factual and concrete manner, the literary artist takes up the task of representation through multiple modes. It is not an easy society to portray in literature. In contemporary Ghana, which Armah uses as the locale of his novel, no values are sacred; expediency is the norm and the honest are made to feel inferior and lonely. Feelings of anguish and despair are predominant in the works of Ayi Kwei Armah. The Beautiful Ones Are Not Yet Born presents a corrupt and decadent society. How effectively can the realist mode portray a sense of deep despair? What are the layered levels at which language and narration must function to achieve the wrenching impact the author seeks to impart? What visual imagery or symbolic language can a writer use to convey the unconveyable? How can such elements be woven seamlessly into a realistic narrative? This paper examines some of these questions and attempts to unravel the multiple ways in which descriptive language, revolting metaphors and nauseating scatological imagery are employed in the text and their efficacy.

In The Beautiful Ones Are Not Yet Born, Armah right from the first page captures through his language and tone the decadence of a society where people have lost the zest for life. It is a modern wasteland where the living dead move about mechanically with no purpose. While the novel has a definite structure, the climax coming with the overthrow of Nkrumah's reign, thematically there is very little actual development. The novel begins and ends with bus rides and during both those journeys bribes are offered. In spite of all that has happened in between-the fall of the government and the vindication of the moral stand of the unnamed protagonist-nothing much has actually changed in the external texture of life, the wheel comes full circle with the last bus ride. Although presented along a definite historical and geographical axis, the early sections of the novel have a certain timeless, placeless quality. The events described here could happen anywhere and this deliberate lack of precision is increased by the fact that the protagonist is never named. Throughout the novel he is referred to as 'the man' or 'he'. His values are different from those held by his family, his colleagues and those around him. 'The 
man' is not assertive in his moral stand; infact he is almost apologetic about being different, but he knows that he cannot change. This unheroic hero goes through life with a certain amount of bafflement at his incompatibility with other people's way of viewing things.

The novel begins inside a dark dreary bus. Armah's tone and deliberately deadpan descriptions thrust us right into a land of apathy and decay where living is merely a matter of day to day existence: "People were still only bodies walking in their sleep. But what could a conductor take, even from a body that has yet to awake, when all the walking corpse hols out is the exact fare itself, no more, no less?" (p.2)

Though Armah presents a corrupt decadent society in a forceful manner, he is not the first novelist to attempt this. Achebe and Soyinka have in their novels presented with equal success, a degenerate crippled society. Armah's novel then, is not unique in this regard. But The Beautiful Ones Are Not Yet Bornis important for two reasons: Firstly, what Armah has to say is as important as how he says it. The language and the tone of narration are crucial dimensions of the novel. Secondly, Armah probes deeply into the relationship between an individual and society without simplifying the complex tensions. The metaphors used by Armah in The Beautiful Ones Are Not Yet Born contribute greatly to our awareness of the decay, waste and filth that are part of the society. The first chapter gives us a description of the dustbins which are overflowing with filth and slime: "The thing had been a gleaming white sign when it was first installed, and that was not so very long ago. Now even the lettering on it was no longer decipherable. It was covered over thickly with the juice of every imaginable kind of waste matter." (p.7)

This description can be extended to become applicable to the whole country. It is newly independent; freshly installed. But now it is filled with waste matter and covered with squalor. The descriptions of filth and scatological references are undoubtedly nauseating, and as some critics have felt, "beyond the bounds of decency." But Armah has a specific purpose in introducing these details. He uses actual physical filth as a powerful metaphor for other kinds of degeneration thereby intensifying our revulsion. Language here 
becomes a tool for the writer to convey the sense of decay at many levels.

Armah deliberately chooses images that create feelings of horror and disgust. A young boy Aboliga brings a book of freaks and oddities to school and shows his friends his favourite picture - that of a man- child: "within seven years it had completed the cycle from boyhood to infancy to youth to maturity and old age, and in its seventh year it had died a natural death... The man- child looked more irretrievably old, far more thoroughly decayed than any ordinary old man could ever have looked." (p.63) Again, this image and the descriptions are applicable to Ghana also. In its pursuit of rapid westernization and material welfare, Ghana has also become old and decayed before its time. In addition to these images we have detailed descriptions of rotting banisters, overflowing toilets and caked cisterns.

The use of repulsive details has a definite purpose. As S.A Gakwandi says, "the stench of the putrefying matter becomes one with stench of despair in the men who are walking about. The sounds, the smells, the sights and the thoughts of the people all mingle into a single rhythm of death and decay".(1977) By using images of filth and excreta and phrases such as "oozy slime" and "juicy offal", Armah deliberately shocks the reader into a realization of the prevailing moral and physical squalor. In fact, the stench and the scatological details go beyond realism to become symbolic motifs in the novel, culminating in the last chapters when during the coup the situation gets reversed: The ordinary protagonist, who was considered by those around him to be inferior to Koomson, becomes Koomson's saviour. The fact that Koomson can escape only through the toilet hole in the man's house (which, on an earlier visit Koomson had considered unusable) underlines the ultimate reversal of values. The excremental metaphor shows the use of language as a prod. In the disgust/discomfort it produces it also forces us to face what we often couch in euphemistic language or turn away from.

Eldred Jones, in his discussion of the language of The Beautiful Ones says 'Somehow it is unpleasantly apt' (1969)A low, disgusting deed becomes more vivid when the language and images used are suitably squalid and repulsive. These examples from the text show 
language can even be therapeutic; it gives the common man an outlet to convey repressed feelings. Taboo words and curses are often the weapon of those who are helpless; and its use cathartic to some extent, even as it reinforces both the state of impotence and moral/ethical decadence of the society.

How were these leaders to know that while they were climbing up to shit in their people's face, their people had seen their arse hole and down away in disgusted laughter?(p.82).

The poet is there, serving power and waiting to fill his coming paunch with crumbs. He will no doubt jump up to go fit his tongue into new arses when new men spring to shit on us (p.89)

He was trying to speak like a whiteman and the sound that came out of his mouth reminded the listener of a constipated man, straining in his first minute on top of the lavatory seat (p.125)

The vulgar physical metaphors are a scale to determine the degree of the author's moral revulsion. This is a deliberate strategy employed by Armah. Here language becomes a weapon, sharp, powerful, capable of inflicting violence and pain. Sensory imagery, especially of touch, smell and taste also contributes greatly to our constant sense of disgust and outrage. The banister in the office building is slimy to the touch, coated with something watery, brown and oozing when Koomson, the corrupt politician, takes refuge in the house of the hero, a bad smell emanating from his fills the tiny room, almost suffocating the hero and his wife. Since there is no logical explanation for this smell, it becomes a powerful and outrageous metaphor formoral decay. As Koomson opened his mouth to speak, there was a "stench of rotten menstrual blood." Such metaphors reach their symbolic climax when Koomson has to make his escape through the toilet hole in the protagonist's house. On the literal level this shows the total degradation of the wilypolitician, while on the symbolic level it ties up the various references to filth and excreta in a final image of unbearable squalor. But as A.A Aidoo says, 'This type of purgative exposure, however painful it is, is also necessary.'(1973)If readers are repelled, shocked or disgusted, theyare responding to the text exactly as the writer wants them to. There is a constant sense of ambivalence in the reading of the text; an appreciation of the skill 
of the artist, the merciless expose of the critical realist who uses language like a virtuoso to draw many tunes provides intellectual stimulation and admiration.

While Armah may use strong language and be brutally frank, he does not exaggerate in order to increase the impact of his novel. The society he presents is corrupt and degenerate. Armah does not spare anyone. His anger and disgust are aimed at everybody who is directly or indirectly responsible for the condition in Ghana. Some readers and critics have found this attitude unfair. They have felt that Armah is too clinical, that he distances himself too much and his portrayal is not tinged with any understanding or sympathy. Indeed, Armah is ruthless in his strictures, merciless in his criticism, presenting a bleak wasteland. But he does not take up a critical stands merely because it is the fashion to do so. One cannot miss the transparent rage that propels the novel forward. It is this genuiness that moves A.A Aidoo to say, "The author is contemptuous of us - but lord do we deserve it".(1973)

The novel ends when a military coup replaces civilian rule in the country. But nothing has essentially changed. 'The man' helps Koomson escape from the new military ruler. Koomson sails away in a fishing- trawler and 'the man' swims back ashoresymbolically, purified by the sea. It is ironic that 'the man' who least needs purification should have to go through this rite. His subconscious longing, expressed during his long walks on the sea shore is now fulfilled.

The end of the novel at first seems to present us with a rather bleak, hopeless future for Ghana. Going home in the morning after the coup, the protagonist sees a bus rider bribing the police. At the back of the bus is the slogan,' The Beautiful Ones Are Not Yet Born' written in an oval shape. The national game is still on, and a change of rule has made no difference to the mores of life. As Eldred Jones writes: "the episode which culminates in the slogan is another of many sharp symbols or symbolic situations with which the Ayi Kwei Armah punches home his theme of continuing corruption."(1969).

Charges of obscenity and vulgarity, a sense of outrage at such disgusting language, accusations of violating literary norms, 
outraging artistic freedom are all too often levelled against texts and authors who break literary conventions, use tabooed language and scatological imagery. What needs to be foregrounded here is the sharp and pointed appropriateness of such usage, its unquestionable effectiveness in conveying the message of the moment and the artistic skill and merit that informs such a usage.

\section{Reference}

Aidoo, A. A. (1977). African writers on African writing. London: Heinemann.

Armah, A. K. (1969). The beautyful ones are not yet born. London: Heinemann International Literature \& Textbooks.

Fitch, B., \& Oppenheimer, M. (1966). Ghana: End of an illusion. New York.

Gakwandi, S. A. (1977). The Novel and contemporary experience in Africa. London: Heinemann.

Jones, E. D. (1969) AyiKweiArmah. The Beautiful Ones Are Not Yet Born. African Literature Today.

Naipaul, V. S. (1984) Finding the Centre. London: Andre Deutsch. 